\title{
From Periphery to Epicentre: The Resilience of Zimbabwean Immigrant Children Despite 'Walking a tightrope'
}

\author{
Kudzayi Savious Tarisayi \\ ORCID iD: https://orcid.org/0000-0003-0086-2420
}

\section{Sadhana Manik}

ORCID iD: https://orcid.org/0000-0001-7687-0844

\begin{abstract}
A plethora of discourses have emerged on Zimbabwean migrant teachers in South Africa and on immigrant children in general in contemporary literature. Zimbabwean teachers have been known to migrate to South Africa with their children, however, the acculturative experiences of their accompanying children, remain an under researched area. This article seeks to explore the acculturative experiences of Zimbabwean immigrant children, through the lens of their parents who are teachers working in Eastern Cape Province of South Africa. The data is from a qualitative interpretive study on migrant teachers in the Eastern Cape. The paper draws on data from semi-structured interviews of ten Zimbabwean immigrant teachers. The theoretical aspects of the paper are guided by the social capital theory and the concept of acculturation. The findings highlight parental support and a hope for their children being bicultural in South Africa. However, immigrant children encounter a language barrier at school, and are subjected to humiliation due to their underdeveloped social capital. Nevertheless, they demonstrate that they are sufficiently resilient, with great expectations for achievement. They accumulate sufficient socio-cultural capital to assimilate, while garnering respect, admiration and confidence and to become high academic achievers.
\end{abstract}

Keywords: acculturation, Zimbabwean immigrant children, afrophobia, survival strategies, social capital, resilience

\section{Introduction}


There is a plethora of studies on the experiences of Zimbabwean immigrant teachers in South Africa (de Villiers \& Weda 2017; Hungwe 2013; Manik 2013; Ranga 2014; Singh 2013; Tevera 2013). These studies have established that Zimbabwean immigrant teachers navigate a multiplicity of challenges in South Africa (SA). Internationally, Bryant (2005) established from a study in Southeast Asia that migration poses numerous challenges to the children of migrants. However, surprisingly, contemporary literature has been confined to the experiences of Zimbabwean migrant teachers without necessarily extending the discourse to their dependents and more specifically their children. Nevertheless, there is a body of literature on immigrant children's schoolbased experiences in SA in general but herein they are largely constructed as vulnerable (Sidhu \& Taylor 2012). Adebanje et al. (2014) opine that not much is known about Zimbabwean immigrant children in terms of their acculturation in schools and SA society. Thus, the experiences of children of Zimbabwean migrant teachers remain an under researched area, especially in terms of social capital and school experiences (Isseri et al. 2018). Resultantly, this study sought to extend the literature on Zimbabwean immigrants in SA by exploring the experiences of Zimbabwean children but through their parents' (immigrant teachers) lens. The choice to use parents was due to ethical concerns as immigrant children can be perceived as vulnerable (Liamputtong 2011) thus researching those who are vulnerable demands particular actions from the researcher to protect the children and given that the researchers were a physical distance away from the research site, the decision was taken in the interest of the children to access their acculturative experiences via their parents.

The first section of this paper provides some available statistics on immigrant children and a background to the research problem. The theoretical lens adopted for this study is discussed in the second section of the paper. The researchers then present the research methodology utilised in this study followed by a discussion of the findings and theorisation. Concluding remarks on social capital and the acculturative experiences of the children of Zimbabwean immigrant teachers sum up the paper.

\section{Statistics on Immigrant Children}

While there is a paucity of reliable statistics on immigrant children in South Africa, globally 30 million of the 258 million people living outside their country of their birth, are children (UNICEF 2018). The 2016 Community 
Survey revealed that there were 1578541 people living in South Africa who were born outside of the country (of which 175709 were children) (Statistics South Africa, 2016). Manik (2013) estimated that there were 40000 Zimbabwean immigrant teachers in South Africa; however, there were no statistics disclosed related to the children of these immigrants. This study adopts the definition of a child as a person below the age of 18, as espoused by Article 1 of the United Nations Convention on the Rights of the child (UN 1989). Thus, the researchers confined their analysis to the children of Zimbabwean immigrant teachers below the age of 18. Additionally, the study focused on the children who accompanied the Zimbabwean immigrant teachers who are currently living in one province of South Africa.

\section{Immigrant Children in South Africa}

Studies on the experiences of immigrant children in South Africa have centred on their school-based experiences and the common narrative has been that of their helplessness. This growing body of literature has focused on the challenges faced by immigrant children in South Africa. Ncumisa and Mfubu (2016) reported that foreign minor children in South Africa face a struggle to acquire documents in South Africa and may at times be enrolled in schools without the requisite identification documents. Isseri et al. (2018: 39) established that immigrant children faced 'language and cultural barriers, social isolation and exclusion, and bullying and discrimination that heightened their vulnerability in schooling spaces'. However, the study by Isseri et al. (2018) was confined to schooling spaces without focussing on an extended picture from their parents' acculturative experiences of their children. Additionally, Mathe (2018) stated that even unaccompanied immigrant children have problems in accessing education; there is discrimination in South African schools; there are documentation challenges as well as emotional and psychological distress. Ncumisa and Mfubu (2016: 423) established the vulnerability of foreign minor children in South Africa despite the country having 'arguably the most progressive child protection mechanisms in Africa'. Of course, it can be argued that it takes more than the establishment of protection mechanisms to adequately support and protect foreign minor children in South Africa. In a legal narrative on the experiences of foreign minor children, Ncumisa and Mfubu (2016: 423) report that 'there are disparities between the law and the implementation of the law'. Ackermann (2017) also 
noted identity documentation challenges in the present child protection framework in South Africa. The above studies all illuminate an assortment of challenges that immigrant children are confronted with when they are in South Africa. However, a common methodological concern is that these studies have relied mostly on data generated in the school context and through the perspectives of the immigrant children. Immigrant children's experiences elucidated through the lens of their parents have been absent. Therefore, there is a need to fill this gap on immigrant children's experiences extending across the following contexts: their home, community and school. Additionally, this study explores the acculturative experiences of the children through of the lens of those closest to them, namely their parents, Zimbabwean immigrant teachers.

\section{Acculturation}

Contemporary literature on the experiences of immigrant children is largely informed by cultural differences between the sending country and host country. These differences between the culture of the host country and that of the sending country have been established to have implications for immigrant children around the world. Masheti (2014), Ying and Han (2007) revealed that there are conflicts between immigrant parents and their children in terms of adopting the culture of the host country. Seminal anthropology scholars Redfield et al. (1936:149) define acculturation as a phenomenon 'which results when groups of individuals having different cultures come into continuous first-hand contact, with subsequent changes in the original cultural patterns of either or both groups'. Thus, acculturation is about adaptation to a different society (Berry et al. 2006). Berry (1997: 6) advances that acculturation can unfold through four means: integration wherein immigrants are propelled towards the host culture whilst keeping their home culture. This has been referred to as biculturalism (Rumbaut 1995). Secondly, assimilation - which is the loss of the home culture in favour of the host culture, thirdly is separation - where immigrants are divorced from the host culture and fourthly, marginalisation, where immigrants have very little interest in either the home or the host culture.

Renzaho et al. (2017: 01) argue, 'youth in new migrant families become contested sites of culture as they try to balance integration into the new culture while maintaining their originating country's cultural values'. The 
culture at school has been known to lean on the mainstream culture in a country (Adebanje et al. 2014) which can influence immigrants. It has been noted that intergenerational acculturation conflicts arise when the acculturation process of immigrants' children clash with the cultural norms deemed acceptable by their parents. Resultantly, research indicates that immigrant children strive to balance the cultural norms in the host country against acceptable norms from their home country. Additionally, a key aspect of acculturation is language acquisition.

\section{Social Capital Theory}

This study is guided by the social capital theory which has relevance for immigrant children's acculturative experiences in the host society. Isseri et al. (2018) asserted that the social capital theory should be examined for its significance in researching immigrant children. There is a plethora of definitions of social capital in current literature (Castiglione et al. 2008; Dill 2015; Scrivens \& Smith 2013). However, this paper is guided by the view that social capital is 'a culture of trust and tolerance, in which extensive networks of voluntary associations emerge' (Inglehart 1997: 188). The networks of immigrant children at home, in the community and school are conceived as social capital. Gauntlett (2011) states that the conceptualization of social capital over the last three decades is informed by the work of Pierre Bourdieu, James Coleman and Robert Putnam. The social capital framing for this study is informed by the work of Pierre Bourdieu. For Bourdieu, social relations enable the participants to accumulate resources available in their proximity. Bourdieu (1985: 255) further reveals that social capital is in essence 'the grease that enables the machine of opportunity to operate'. Therefore, opportunities for immigrant children to integrate are enabled by their social capital. Additionally, Bourdieu argues that social capital is relative, depending on the quantity and quality of an individual's social networks. However, Bourdieu's social capital theory has been critiqued because of its inability to measure social capital. Hayes (2009: 12) contends 'neither social capital nor its effects can be accurately measured in comparable ways'. Despite this apparent weakness of the social capital theory, this study draws from the same theory because it does not seek to measure the social capital of the immigrant children of this sample. The study rather attempts to understand the acculturative experiences of the immigrant children, whose parents are Zimbabwean 
immigrant teachers in one coastal province of South Africa, one of the areas which has been repeatedly identified as a zone of xenophobic violence in South Africa. However, recent literature argues that the violence against black foreigners in South Africa as 'Afrophobia' (Tarisayi \& Manik 2020). The latter term refers to South Africans who are black African, who show a hatred for other black Africans from outside SA.

\section{Research Tools and Data Generation}

The researchers generated data in one purposively selected rural province in South Africa that has been experiencing Afrophobic violence since 2008. The study sought to understand the acculturative experiences of Zimbabwean immigrant children through the lens of their parents. Hence, the researchers' adoption of a qualitative methodology. Creswell and Poth (2018) and Cohen et al. (2018) state that qualitative research seeks to gain an understanding of people's perspectives. Therefore, this study pursued an understanding of the phenomenon of immigrant children's acculturative experiences. Additionally, the study falls within the interpretive paradigm. According to Cohen et al. (2018: 19) the interpretive paradigm 'is characterized by a concern for the individual'. A case study style of research of one rural province in South Africa was utilised 'to portray, analyse and interpret the uniqueness of real individuals and situations through accessible accounts' (Cohen et al. 2018: 188). Data was generated using semi-structured narrative interviews with a purposively selected sample of ten Zimbabwean immigrant teachers. Brinmann and Kvale (2015: 3) opine that an interview 'attempts to understand the world from the subjects' point of view, to unfold the meaning of the experience, to uncover their lived world' which is what we attempted to unpack in this study. The researchers utilised thematic content analysis to identify themes in the data generated from the semi-structured interviews. Braun and Clarke (2006: 77) state that thematic analysis is, 'a method of identifying, analysing and reporting patterns (themes) within data'. The researchers obtained ethical clearance for the study from the University of KwaZulu-Natal (Protocol reference number: HSS/1074/018PD). Additionally, the researchers sought and obtained gatekeepers' permission from the Department of Education.

Table 1 below shows the profiles of the participants in this study.

\section{Table 1: Demographic details of participants and their children}




\begin{tabular}{|c|c|c|c|c|c|}
\hline \multirow{2}{*}{$\begin{array}{c}\text { Pseudonym } \\
\text { of } \\
\text { participant }\end{array}$} & \multirow{2}{*}{$\begin{array}{l}\text { Number of } \\
\text { years in } \\
\text { South } \\
\text { Africa }\end{array}$} & \multicolumn{3}{|c|}{ Gender of children } & \multirow{2}{*}{$\begin{array}{c}\text { Ages of } \\
\text { participants' } \\
\text { children } \\
\text { (years) }\end{array}$} \\
\hline & & $\mathbf{M}$ & $\mathbf{F}$ & Total & \\
\hline \multirow[t]{2}{*}{ Brenda } & \multirow[t]{2}{*}{3} & \multirow[t]{2}{*}{1} & \multirow[t]{2}{*}{1} & \multirow[t]{2}{*}{2} & 10 \\
\hline & & & & & 4 \\
\hline \multirow{3}{*}{ Brian } & \multirow[t]{3}{*}{6} & \multirow[t]{3}{*}{1} & \multirow[t]{3}{*}{2} & \multirow[t]{3}{*}{3} & 18 \\
\hline & & & & & 9 \\
\hline & & & & & 6 \\
\hline \multirow[t]{2}{*}{ Chipo } & \multirow[t]{2}{*}{10} & \multirow[t]{2}{*}{0} & \multirow[t]{2}{*}{2} & \multirow[t]{2}{*}{2} & 10 \\
\hline & & & & & 7 \\
\hline \multirow[t]{2}{*}{ Faith } & \multirow[t]{2}{*}{7} & \multirow[t]{2}{*}{1} & \multirow[t]{2}{*}{1} & \multirow[t]{2}{*}{2} & 9 \\
\hline & & & & & 7 \\
\hline \multirow[t]{3}{*}{ Freedom } & \multirow[t]{3}{*}{5} & \multirow[t]{3}{*}{1} & \multirow[t]{3}{*}{2} & \multirow[t]{3}{*}{3} & 16 \\
\hline & & & & & 10 \\
\hline & & & & & 8 \\
\hline \multirow[t]{2}{*}{ Joan } & \multirow[t]{2}{*}{3} & \multirow[t]{2}{*}{1} & \multirow[t]{2}{*}{1} & \multirow[t]{2}{*}{2} & 15 \\
\hline & & & & & 13 \\
\hline Major & 15 & 2 & 0 & 2 & 17 \\
\hline & & & & & 5 \\
\hline Priscilla & 5 & 1 & 0 & 1 & 11 \\
\hline Ruth & 10 & 1 & 2 & 3 & 17 \\
\hline & & & & & 15 \\
\hline & & & & & 11 \\
\hline Tawanda & 5 & 1 & 1 & 2 & 16 \\
\hline & & & & & 14 \\
\hline
\end{tabular}

Table 1 shows the profiles of the ten participants in this study relating their experiences of their 22 children. The researchers utilised pseudonyms to protect the identities of the Zimbabwean migrant teachers as guided by the work of Wassenaar (2006) on acceptable research ethics (beneficence, nonmaleficence and anonymity). The profiles of the participants indicated that all the participants had brought at least one child to South Africa who was living 
with them at the time of the study. Additionally, all the participants had been living in South Africa for a minimum of three years.

\section{Findings and Discussion}

The findings reveal numerous acculturative challenges in schools which spills over into the home for immigrant children. Isseri et al. (2018: 40) who undertook a school-based study refers to the generalised idea of negative experiences as 'struggles' in the school environment. These challenges included language proficiency difficulties, and learners being identified as the 'other' through their names, dressing and hairstyles which had repercussions for them being targeted through subtle forms of Afrophobia. Acculturative stress for immigrant children took numerous forms in various spaces. However, they demonstrated their agency in selected ways and their increased language proficiency over time resulted in them making social capital inroads, achieving several successes in schools in the host country.

\section{On the Periphery: Language Proficiency and 'Outsider' Status}

The Zimbabwean immigrant teachers who participated in this study revealed that their children experienced language-related constraints which marginalised them and hampered their ease of adaptation to life in South Africa. Priscilla stated,

My child is severely affected by language constraints especially at school. During break time local children switch to vernacular languages which makes my child feel that he is an outsider. I feel that my child is being hindered in social development due to language constraints.

Joan also explained how language problems affected her children's social interactions,

They sometimes have to turn down invitations for [to] outings and birthday parties because they know that their peers will be using local languages during the fun. Efforts to hang out with [socialise with] 
other Zimbabwean families feel like we are imposing friends on my children.

The above empirical evidence indicates that language proficiency was a stumbling block in the smooth integration of immigrant children at school and in the community. The inability to converse in the local indigenous languages isolated the children during social events and eventually some children began to shun outings and birthday parties as a result. It was significant that the immigrant family attempted to reduce this 'acculturative stress' (Adebanje et al. 2014) by harnessing existing expatriate social networks to compensate for their children's lack of success in their social networking attempts. Thus, the immigrant family endeavoured to ensure that children were in what Isseri et al. (2018: 53) refers to as a 'safe, empathetic and protective space'. In retreating to expatriate social networks, immigrant parents attempted to cushion their children against acculturative stress.

It was evident that language constraints led to the labelling of immigrant children as 'outsiders' and this thread of outsider/insider and how these immigrant children make inroads towards the epicentre to gain social acceptance, is continuously weaved across the findings in intricate ways (being an outsider/ in the periphery) for its effect in immigrant learners' social capital development and their social networking efforts in moving towards the epicentre. Acculturative stress was thus evident in a variety of school spaces: in the classroom, during break time and on the sports field. The findings also revealed that immigrant children's lack of proficiency in the indigenous languages was again a constraint, impacting on their attempts to: integrate into the schools' cultural events, demonstrate camaraderie and in their individual participation in extra-curricular activities. Chipo stated,

My children used to be passionate about sporting activities but ever since we came to South Africa they seem no longer interested. Upon inquiry they told me it's difficult to participate in team sport if you are not fluent in the local language. The coaches and peers assume that all black children are fluent in the local language. They can't even cheer [for] their school team because of language constraints.

The immigrant children were purposefully missing opportunities to extend their social capital and nurture friendships by avoiding activities and events 
due to their language deficiencies. Faith explained,

He doesn't want to go down [out of the classroom] in break time [lunch break] because when they're in their jovial moods, they forget he is there and communicate in the indigenous language....so he doesn't want to play in a group, he opts for a conversation, so he is not overpowered.

Brenda also reported about the alienation that her children experienced,

My kids are playing catch up in extra-curricular activities at school. The traditional music and dance are both alien to them. I hope eventually they will be able to learn and be able to participate fully.

The parents, though optimistic and advocating for biculturalism, acknowledged that their children were severely constrained in their participation in extra and co-curricular activities at school, by virtue of being immigrants. Language constraints were experienced in social and team sport activities at school and it prevented the children from adequately communicating with their peers. Additionally, immigrant children were struggling to cheer on their school sports team and to be part of the camaraderie of their school as a result of language constraints.

\section{Identification of the Other, the Makings for Afrophobia?}

The participants indicated that schools became the sites where their children were identified as the 'other' in their interactions due to their names, language/accent, hairstyles and dressing. Initially immigrants have been known to experience a 'culture shock' in a new environment (Manik 2005). Brian stated,

My son complained about people laughing at his Zimbabwean first name and surname. People said that his name sounded strange and awkward. This embarrasses him everywhere he goes'. Resultantly, Brian revealed, 'In order to overcome the hindrances caused by my children's 'unfamiliar' foreign names, they now tell people shortened names. They tell their teachers and peers easier ways to call their 
names, e.g. Chichi instead of Chiedza and Kutso instead of Rukudzo'.

Tawanda added 'Foreign names always prove tricky for the locals. My children have resorted to using their middle English names or shortened versions of their names'. Immigrant children thus began using their pet names instead of their full names in order to assimilate. Pet names made it easier for their teachers and peers to call out their names and it thus enabled the immigrant children to socialise more easily because the names became easier to pronounce for the locals. This was the first step to becoming accepted by their peers and teachers. The parents indicated that their children complained about being subjected to embryonic forms of xenophobia, where they were laughed at by the local children. Major narrated,

Xenophobia can take less obvious forms. For example, migrant children are easy targets of xenophobic jokes. For example, at my child's school, there is one joke about foreigners who try to learn isiZulu and when they are asked to give the name of an elbow in the language, they say [the equivalent of] 'small knee' in isiZulu and get ridiculed. It seems the ridiculing made them more determined to be fluent in isiZulu.

The local children also found it amusing to teach immigrant children inappropriate isiXhosa words. Faith, another parent drew attention to this:

The young ones teach my child but it's not isiXhosa that he needs to know, they will trick him...then they start laughing. When he goes and ask my neighbours they ask 'aah, where did you learn this?' and my son would have said it so confidently.

This strand of xenophobia is Afrophobia and it appears embryonic because it is less obvious when compared to the intermittent violence seen in the streets of SA society since 2008. It is accepted in the literature (see e.g. Adebanje et al. 2014) that language, a strand of social capital, is a conduit to being accepted into the host culture and thus language proficiency facilitates immigrant learners' integration into the host society. Thus, immigrant children are identified as being located on the periphery of society and are targeted by the local children for their lack of expertise in the indigenous languages. 
Additionally, contrary to the argument that learning the local languages cushions migrants from discrimination, this study exposed that attempts by the immigrant children to empower themselves and learn the local languages are not met with understanding by their peers. Instead, it led to some of the immigrant children being used as vessels of afrophobic amusement which culminated in socio-cultural exclusion expressed through the mechanisms of social exclusion in numerous school spaces. This resultantly constrained their participation in extra and co-curricular activities. It was interesting to note that the constraints were both self-imposed as well as imposed by others.

This paper argues that despite immigrant children being negatively stereotyped and marginalised in schools, they demonstrated their agency in being resilient, showing how irrepressible and resolute they were to succeed in the host country. Brenda explained,

My children complained about xenophobic jokes. I think some of the jokes targeting my children are due to their dressing and inability to communicate in isiZulu. The situation used to be very bad when we first arrived in South Africa but things are now improving.

Social capital, according to Bourdieu (1985) ought to strengthen and be of benefit to an individual, however, immigrant children's attempts to extend their social capital by making friends, participating in events and learning the language, opened them up to discrimination. In addition, it can be argued that the quest for acceptance by the immigrant children was not initially supported by their local peers. Hence, it can be argued that the afrophobic jokes were a confirmation of Bourdieu's view on conflict in society. Siisiainen (2000: 10) states that according to Bourdieu, 'conflict is built in society. People can find that their expectations and ways of living are suddenly out of step with the new social position they find themselves in ...' Therefore, the experiences of immigrant children as demonstrated in the afrophobic jokes (among their other challenges) reflect conflict in society. Additionally, their local peers finding amusement in the immigrant children's lack of language proficiency, can be viewed as a betrayal of trust amongst peers. The betrayal of trust established in this study is in contradiction to Bourdieu's social capital theory. Bourdieu argues that trust is enhanced through membership of a group, such as being in the same class in a school, however, attempts by immigrant children to successfully interact within this group exposed them to afrophobic jokes. 
Additionally, identification of the 'other' was revealed through unnecessary questioning of the immigrant children in school by their peers and strangely by teachers who are expected to show care and sensitivity. Isseri et al. (2018) did reveal discriminatory attitudes expressed by teachers towards immigrant learners. In the current study discriminatory questioning by teachers and other children was revealed by Freedom, a parent, who stated,

My children complain of being subjected to undue questioning from teachers and peers about their home country. There are stereotypes which are perpetuated against children of migrants based on media reports that things are difficult in our home country.

But, there are times when teachers ask questions and inadvertently, it identifies the student as an immigrant. For example, Faith explained when his son attended a briefing session in preparation for a quiz and the teacher explained everything in isiXhosa and her son said,

'I hardly got anything' and when the teacher asked 'do you all understand?' he said 'no' and then the teacher started explaining again in isiXhosa, so he had to say 'in English, please' which drew attention.

When immigrant children are subjected to such probing questions by teachers at their schools, it draws attention to them being identified as foreign - the 'other'. Isseri et al. (2018: 53) referred to 'an ethic of care' that family support systems demonstrated but clearly this also has relevance in schools. In schools, teachers ought to be the instruments of pastoral care for learners and this was absent for some immigrant children as teachers, who were supposed to be their protectors, were identifying them as being different and drawing undue attention to them.

\section{'Walking a tightrope'}

The participants also mentioned their children's cultural experiences of dressing and hairstyles being critical to their integration into the South African society. Major explained,

Back home [Zimbabwe] school children have conservative haircuts. 
Now my children are talking about 'afros' and dreadlocks since coming to South Africa. There is a perception among my children that they need to express themselves with their hairstyles.

Ruth furthered this notion of how immigrant children have to negotiate the differences between the home and host cultures,

My children 'walk a tightrope' when it comes to dressing and hairstyles. At home we try to teach them conservative dressing and hairstyles. When they get to school, this makes them feel out of place. They seem not sure which dressing style to follow between that of their peers or what we teach them at home.

It was evident that different hairstyles and dressing were cultural signs of being the 'other' in school and that the society with immigrant learners is easily identified by virtue of such. What seems to emerge is a shedding of cultural traditions from the home country in favour of those of the host country, by the immigrant children. This can potentially lead to family conflict as immigrant children negotiate life in the host country.

The study established that in this sample, the children of Zimbabwean immigrant teachers struggle to find the right balance in seeking to conform in their dressing and hairstyles with the local population. This leads to contestations within the family with parents expressing their views about what is appropriate behaviour (as Major explained). There is a cultural clash between the parents' expectations and what the children are exposed to and attracted to at school and in SA society. The parents expected their children to dress conservatively and to conform to Zimbabwean values and norms (e.g. on how to excuse yourself when one wants to use the bathroom and not be so forthright). But these parents' expectations for their children are in direct conflict with the culture and norms that their children are exposed to in South Africa. In attempting to build their social capital, the children can be viewed as walking a tightrope in trying to strike a balance between their parents' expectations and blending in with their more liberal peers in the community and at school. Therefore, the dress codes and hairstyles were contested cultural terrains in the lives of the immigrant children. Consequently, the children have to circumnavigate the desire to conform to the status quo at school (and build their social capital) as well as the culturally conservative norms of their parents 
emanating from their home culture. Living such a dilemma concurs with the findings by Renzaho et al. (2017: 01) that youth migrants 'were contested sites of culture'. Therefore, it can be argued that immigrant children are constantly negotiating a life in two cultures. This continual negotiation of these different cultures leads to the metaphor of walking a tightrope.

Tawanda also narrated,

My children initially had problems because of cultural differences. They started their education in Zimbabwe and when we moved to South Africa they were struggling to adapt. My children were ridiculed for the way they dressed, because of cultural differences. Eventually I had to give in and they are now wearing tight fitting clothes like their local peers in order to blend in.

It was evident that the parent was expecting biculturalism, however the child opted for assimilation. The family structure again appears as a compassionate and supportive environment in the host country for immigrant children, and this is clearly revealed here. All the participants were unanimous that the cultural differences between their home country, Zimbabwe and South Africa was demonstrated in the hairstyles and dressing which had significant implications for their children's social integration into the host country's norms. Eventually immigrant children succumbed to the culture in their immediate environment; they assimilated. Tong et al. (2006) have alluded to this when they asserted that immigrant children may trade their home culture and ethnic identity if they give in to the host culture, with assimilation being the outcome. The parents eventually support their children's choices in the host country.

Parents also shared how 'familial input' (Adebanje et al. 2014) may be an attempt to assist in integration into the host country but it can also have unintended negative impacts for the socio-cultural links to home country. Faith shared that,

We tried to encourage my kids [children] to communicate in English at home. I was hoping that will [would] give them an advantage since they are attending an English-medium school. However, I have discovered that my kids [children] feel like outsiders when we have visitors from my home country and we are communicating in our 
mother language. They struggle to express themselves in their mother language. I believe that they also feel the same at school during break and lunch times, when their peers switch to local languages.

This extract reveals that the home environment, can also at times, be a site of immigrant children experiencing being 'othered'.

\section{From the Periphery of Education to Educational Success}

Not being skilled in using the local languages of isiXhosa and isiZulu whilst being African immediately drew attention to the children being immigrants and this had implications for achieving academic success. However, immigrant children found strategies not only to cope but to be accepted into mainstream society and to also thrive. The parents indicated their immigrant children experienced initial difficulties in integrating into the South African education system. Brian stated,

My child born in Zimbabwe [also started school in Zimbabwe] had transitional problems in terms of grading. The grading and content system in Zimbabwe is different from that in South Africa and I had to make him repeat Grade 1 to catch up. This means he could not cope with the new system.

Ruth shared this view:

My children seemed to be overwhelmed by the changes that came with relocating to South Africa. The content taught in school proved a difficulty for them as it is different from the subject content taught in Zimbabwe.

The above quotes highlight that immigrant children did experience difficulties in integrating into the education system in South Africa. The parents indicated that differences in grading and content constrained the integration of immigrant children at school. However, the study revealed that despite these difficulties, immigrant children were steadfast and ended up excelling in their studies. Isseri et al. (2018: 47) argued that 'educational resilience' 'despite adversities brought on by situated conditions' is evident 
amongst immigrant learners. In the current study, Brian stated that his child is,

Performing well in class to earn respect of friends and teachers and it demystifies the stigma associated with being an immigrant.

Joan similarly explained,

My children started making more friends when they excelled in their studies. So it was a matter of proving [oneself] to be smart first before acceptance.

Faith explained the extent of her son's achievement in Mathematics from the time he was 6 years old to now at 13 years,

In the lower grades, he didn't want to participate, he wanted everyone to be at the forefront and him at the back, even when he was good... and he has been number one since Grade Four. He came into my bedroom, I was on study leave, and said to me, 'you are looking at someone who has got through to the next round' (he was representing the district).

From the above verbatim quotes it can be noted that excelling in schoolwork not only became an acculturative survival strategy but it encouraged learners to attain academic and social success. The immigrant children realised that excelling in class earned them the respect of their peers and teachers. The children were able to shake off the stigma and stereotyping which came with being a struggling immigrant by excelling in their studies. Interestingly, there also appeared in terms of acculturation experiences, to be a correlation between the age of the immigrant children and their experiences of afrophobia. For example, Major stated,

The experiences depend on their age. My teenage son struggled when we relocated to South Africa. However, surprisingly his younger brother in Grade R did not seem to encounter the same problems. I would say younger children are not xenophobic. They just want to play and learn with their peers.

Brenda shared a similar experience, 
I don't get any complaints from my four-year-old daughter (in preprimary school) but the story is different for my ten-year-old son. My daughter has easily adapted to life in South Africa and made friends. My son is however always complaining about how he is treated by his peers [as a victim of afrophobic jokes].

The above adds an interesting dimension to the acculturation experiences of immigrant children of these Zimbabwean immigrant teachers. It reveals that the experiences vary with their age group and concomitant grade. These findings are consistent with Guerra and Brindle (2017) who state that young migrant children easily adapt and integrate into the host country's way of life. In this present study, the older a migrant child is, the more he/she is subjected to afrophobic tendencies by their peers. Additionally, the findings on the disparities in the experiences of immigrant children which are age related suggests that relocating with younger children (as compared to older children) may enhance their ability to adapt.

\section{Assimilation and Progress}

The study established that the immigrant children assimilated and progressed in the host country. Major explained 'My children had to learn isiZulu language in order to mingle with their peers'. Priscilla indicated the extent of assimilation, 'My child now feels comfortable here (in South Africa) because he is not comfortable speaking the home language in Zimbabwe'. It has emerged that in the households of those Zimbabwean immigrant teachers who opted to be fluent in English, there were unintended socio-cultural consequences for the children. The use of the English language in the households of Zimbabwean immigrant teachers to ensure proficiency in English, led to the neglect of their Shona mother tongue which has led to subtractive bilingualism. This neglect of the mother language by Zimbabwean immigrant teachers in their households eventually marginalised their children, and led them to feel like outsiders, when entertaining visitors from their country.

\section{Conclusion}

The children of Zimbabwean immigrant teachers encountered language pro- 
ficiency and aesthetic challenges (in terms of dressing and hairstyle) in the host country. It was evident that they were negotiating home and host cultures in order to integrate into South African society. The study established that gaining social capital via their attempts at language acquisition and English proficiency for their survival and progress had unintended consequences, such as neglecting their mother tongue and a loss of their home culture. Efforts to blend into society, by learning to speak the local languages resulted in the children becoming targets of xenophobic jokes. It is evident that immigrant children should not be viewed as vulnerable, as they have demonstrated that they are socio-culturally resilient and resolute in their determination to succeed in the host country. Whilst they are shaped by their experiences, they are also forging new negotiated identities. Their efforts, the socio-capital (in language acquisition and academic performance) and cultural capital strides they make, move them from the periphery to the epicentre of SA society.

\section{References}

Ackermann, M. 2017. Unaccompanied and Separated Children in South Africa. Cape Town: Scalabrini Centre of Cape Town. Available at: http://scalabrini.org.za

Adebanje, O.T., N. Phatudi \& C.G. Hartell 2014. The Influence of Familial and Schooling Experiences on the Acculturation of Immigrant Children from Zimbabwe. Mediterranean Journal of Social Sciences 5,20: 1039 1050. https://doi.org/10.5901/mjss.2014.v5n20p1039

Berry, J.W., J.S. Phinney, D.L. Sam \& P. Vedder 2006. Immigrant Youth: Acculturation, Identity, and Adaptation. Applied Psychology: An International Review 55, 3: 303 - 332. https://doi.org/10.1111/j.14640597.2006.00256.x

Berry, J.W. 1997. Immigration, Acculturation and Adaptation. Applied Psychology: An International Review 46: 5 - 68.

https://doi.org/10.1111/j.1464-0597.1997.tb01087.x

Bourdieu, P. 1985. The Levels of Social Capital. In Richardson, J.E. (ed.): Handbook of Theory of Research for the Sociology of Education. New York: Greenwood Press.

Braun, V. \& V. Clarke 2006. Using Thematic Analysis in Psychology. Qualitative Research in Psychology 3,2: 77 - 101. https://doi.org/10.1191/1478088706qp063oa 
Brinkmann, S. \& S. Kvale 2015. Interviews: Learning the Craft of Qualitative Research Interviewing. $3^{\text {rd }}$ Edition. Thousand Oaks, CA: Sage Publications.

Bryant, J. 2005. Children of International Migrants in Indonesia, Thailand, and the Philippines: A Review of Evidence and Policies. Innocenti Working Paper No. 2005-05. Florence, UNICEF Innocenti Research Centre.

Cohen, L., L. Manion \& K. Morrison 2018. Research Methods in Education $8^{\text {th }}$ Edition. London: Routledge.

https://doi.org/10.4324/9781315456539

Creswell, J.W. \& C.N. Poth 2018. Qualitative Inquiry and Research Design: Choosing among Five Approaches. Thousand Oaks, California: Sage.

De Villiers, R. \& Z. Weda 2017. Zimbabwean Teachers in South Africa: A Transient Greener Pasture. South African Journal of Education 37,3: 1 9. https://doi.org/10.15700/saje.v37n3a1410

Department of Social Sciences and Philosophy University of Jyväskylä 2000. Paper presented at ISTR Fourth International Conference 'The Third Sector: For What and for Whom?' Trinity College, Dublin, Ireland July 5-8, 2000.

Dill, A. 2015. Paper on: What is Social Capital: A Review. Basel: Basel Institute of Commons and Economics.

Gauntlett, D. 2011. Making is Connecting: The Social Meaning of Creativity from DIY and Knitting to Youtube and Web 2.0. Cambridge: Polity Press. Guerra, V. \& D. Brindle 2017. Promoting the Social Inclusion of Migrant Children and Young People: The Duty of Social Services. European Social Network. Available at:

https://www.esn-

eu.org/sites/default/files/publications/25.01.2018 VGReview Migration Report_Final.pdf

Hayes, P. 2009. Before Going any Further with Social Capital: Eight Key Criticisms to Address. Ingenio 2:1-23.

Hungwe, C. 2013. Surviving Social Exclusion: Zimbabwean Migrants in Johannesburg, South Africa. Unpublished $\mathrm{PhD}$ Thesis. University of South Africa.

Inglehart, R. 1997. Modernisation and Post-modernisation: Cultural, Economic, and Political Change in 43 Societies. Princeton, NJ: Princeton University Press. 
Isseri, S., N. Muthukrishna \& S.C. Philpott 2018. Immigrant Children's Geographies of Schooling Experiences in South Africa. Educational Research for Social Change 7, 2: 39 - 56.

https://doi.org/10.17159/2221-4070/2018/v7i2a3

Kvale, S. \& S. Brinkmann 2015. Interviews: Learning the Craft of Qualitative Research Interviewing. Thousand Oaks, CA: Sage Publications.

Liamputtong, P. 2011. Researching the Vulnerable. London: SAGE Publications Ltd.

Manik, S. 2005. Trials, Tribulations and Triumphs of Transnational Teachers: Teacher Migration between South Africa and the United Kingdom. Unpublished D.Ed Thesis,. University of KwaZulu-Nata, South Africa.

Manik, S. 2013. Zimbabwean Immigrant Teachers in KwaZulu-Natal Count the Cost of Going under the Hammer. Alternation Special Edition 7: 67 87. http://alternation.ukzn.ac.za/Files/docs/20.4/05\%20Man.pdf

Masheti, N.W. 2014. Psychosocial Well-being of African Migrant Children in Ireland: A Cultural Orientation. Unpublished $\mathrm{PhD}$ Thesis, University College Cork.

Mathe, M. 2018. Experiences, Challenges and Coping Strategies of Unaccompanied Migrant Children in South Africa: Guidelines for Social Work. Unpublished PhD Thesis. UNISA.

Ncumisa, W. \& P. Mfubu 2016. No Future for our Children: Challenges Faced by Foreign Minors Living in South Africa. Annual Health and Medical Records 12, 1: 423 - 441.

Ranga, D. 2013. Teachers on the Move: An Analysis of the Determinants of Zimbabwean Teachers' Immigration to South Africa. Unpublished PhD Thesis. University of South Africa, Pretoria.

Redfield, R., R. Linton \& M. Herskovits 1936. Memorandum on the Study of Acculturation. American Anthropologist 38: 149 - 152.

https://doi.org/10.1525/aa.1936.38.1.02a00330

Renzaho, A.M.N., N. Dhingra \& M. Georgeou 2017. Youth as Contested Sites of Culture: The Intergenerational Acculturation Gap amongst New Migrant Communities - Parental and Young Adult Perspectives. PLoS One 12, 2: 1 - 19. https://doi.org/10.1371/journal.pone.0170700

PMid:28170406 PMCid:PMC5295684

Rumbaut, R. 1995. The New Californians: Comparative Research Findings on the Educational Progress of Immigrant Children. In Rumbaut, R. \& W.A. Cornelius (eds.): California's Immigrant Children: Theory, Research, 
and Implications for Educational Policy. San Diego: Center for UsMexican Studies.

Scrivens, K. \& C. Smith 2013. Four Interpretations of Social Capital: An Agenda for Measurement. OECD Statistics Working Papers, 2013/06, OECD Publishing. Available at:

http://dx.doi.org/10.1787/5jzbcx010wmt-en

Sidhu, R. \& S. Taylor 2012. Supporting Refugee Students in Schools: What Constitutes Inclusive Education? International Journal of Inclusive Education 16,1: 39 - 56. https://doi.org/10.1080/13603110903560085

Siisiainen, M. 2000. Two Concepts of Social Capital: Bourdieu vs. Putnam. International Journal of Contemporary Sociology 40,2, October: 183 203.

Singh, S.K. 2013. Zimbabwean Teachers' Experiences of Xenophobia in Limpopo Schools. Alternation Special Edition 7: 51 - 66.

http://alternation.ukzn.ac.za/Files/docs/20.4/04\%20SSi.pdf

Statistics South Africa 2016. Community Survey 2016. Statistical Release. Statistics South Africa.

Tarisayi, K.S. \& S. Manik 2020. An Unabating Challenge: Media Portrayal of

Xenophobia in South Africa. Cogent Arts \& Humanities 7,1: 1859074, http://doi.org/10.1080/23311983.2020.1859074

Tevera, D. 2013. African Migrants, Xenophobia and Urban Violence in Postapartheid South Africa. Alternation Special Edition 7: 9 - 26.

http://alternation.ukzn.ac.za/Files/docs/20.4/02\%20Tev.pdf

Tong, V.M., C.W. Huang \& T. McIntyre 2006. Promoting a Positive Crosscultural Identity: Reaching Immigrant Students. Reclaiming Children and Youth 14, 4: 203 - 208.

UNICEF 2018. Child Migration. UNICEF. Available at: https://data.unicef.org/topic/child-migration-and-

displacement/migration/

Wassenaar, D.R. 2006. Ethical Issues in Social Science Research. In Terre Blanche, M., K. Durrheim \& D. Painter (eds.): Research in Practice: Applied Methods for the Social Sciences. Cape Town: UCT Press.

Ying, Y. \& M. Han 2007. A Longitudinal Effect of Intergenerational Gap in Acculturation on Conflict and Mental Health in Southeast Asian American Adolescents. American Journal of Orthopsychiatry 77, 1: 61 66. https://doi.org/10.1037/0002-9432.77.1.61

PMid:17352586 
Kudzayi Savious Tarisayi \& Sadhana Manik

Kudzayi Savious Tarisayi Postdoctoral Fellow Geography Education University of KwaZulu-Natal

Durban

tarisayik@ukzn.ac.za

Sadhana Manik Associate Professor University of Kwazulu-Natal

Durban manik@ukzn.ac.za 